\title{
STATE DEVELOPMENT POLICY AND THE
}

TRANSITIONAL ECONOMY: COMMENT

David McKee

Kent State University

Although the analysis which Professor Schultz has givenus is designed primarily to expose deficiencies in the development policy of Alabama, I believe that he has exposed a theoretical issue which is almost classic in the field of development economics. I am referring to the labor-surplus problem set forth by Arthur Lewis in the mid-1950's. The Lewis idea has been expanded by various writers over the years. I will not burden you with a "rehash" of the literature but perhaps a brief outline of the laborsurplus problem as it pertains to Alabama would be in order.

As improvements are introduced in the agricultural sector, the key problem in terms of economic expansion is the ability of other sectors of the economy to absorb surplus labor and thus increase overall productivity, per capita income, and presumably welfare levels. In the emerging nations, surplus labor tends to migrate to urban areas and this may create a whole set of problems in those areas.

The labor-surplus problem as it is emerging in Alabama may be even more pernicious than its counterpart in the less developed countries. One aspect of it which worries me is the fact that much of the migration which is occurring takes the form of migration from the State. Many of the younger agricultural workers are leaving Alabama and state development policy appears to be doing very little to correct this situation, as evidencedby the type of industrial expansion that Professor Schultz has described. As he has pointed out, many of the employment opportunities which are opening up are for women in the post forty-five age group. This of course, has ominous implications for the future viability of the economy of the state.

At the risk of being accused of male chauvinism, I must suggest that the replacement of males by females in the labor force is a serious matter, especially in the light of Professor Schultz's analysis of wage differentials between the sexes. The phenomenon of males of both races dropping out of the labor force has broad socialas well as economicimplications. One is sue which left me curious after reading Professor Schultz's paper was the evident ability of women in the post forty-five age group to secure employment. It is not obvious to me why this should occur. I was especially curious concerning this group's ability to secure rural non-farm employment.

In general, I think that Professor Schultz has done a fine job of exposing the problems which have resulted from changes in the rural-urban mix within the State. I believe, however, that more study would be fruitful concerning labor problems in urban areas of various sizes. Perhaps the consus definition of urban obscures various aspects of the situation, I am speaking now of the obvious differences in labor market conditions between communities of various sizes. I mention this not as a criticism of the current paper but rather as a suggestion for future analysis. The present paper is an efficient exposition of differentials in employment opportunities by race, age, and sex, and thus should pose much food for thought for State development officials not only in Alabama but also in other parts of the country which may be experiencing similar difficulties. 